\title{
Teaching NeuroImages: In vivo visualization of Edinger comb and Wilson pencils
}

Andreas Horn, MD, PhD, Siobhán Ewert, MD, Eduardo J.L. Alho, MD, PhD, Markus Axer, PhD, Helmut Heinsen, MD, Erich T. Fonoff, MD, PhD, Jonathan R. Polimeni, PhD, and Todd M. Herrington, MD, PhD

Neurology ${ }^{\circledR}$ 2019;92:e1663-e1664. doi:10.1212/WNL.0000000000007252
Correspondence

Dr. Horn

andreas.horn@charite.de

Figure 1 Wilson pencils

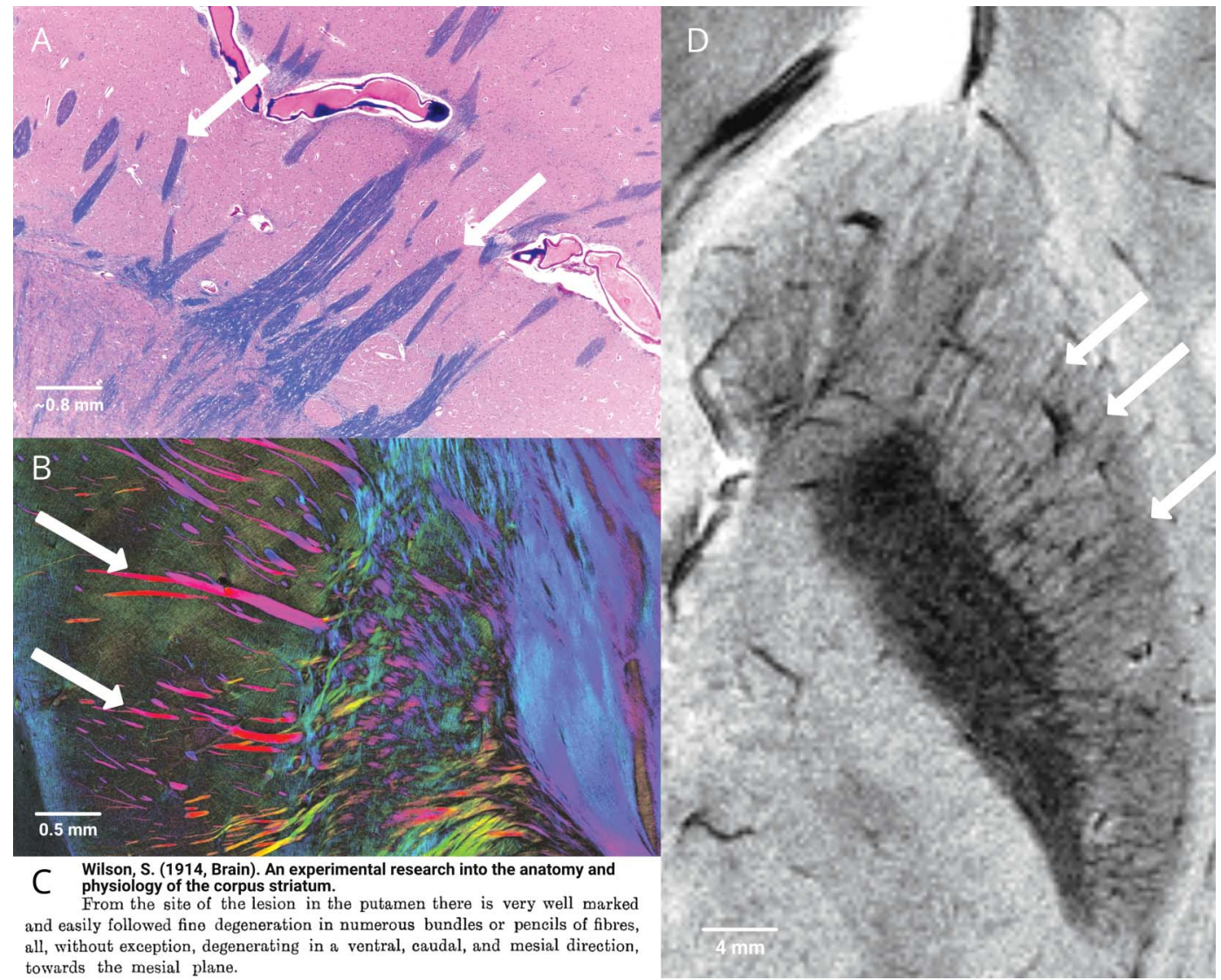

(A) Histologic depiction (image courtesy of Dr. Michael Bonert, McMaster University, CCBY-SA3.0). (B) Polarized light imaging in vervet monkey. (C) First description by Wilson (Brain), reproduced with permission from S.A. Kinnier Wilson. An experimental research into the anatomy and physiology of the corpus striatum. Brain 1914;36:427-492. By permission of Oxford University Press, available at: academic.oup.com/brain/article/36/3-4/427/309802? searchresult=1. For permissions, please email journals.permissions@oup.com. (D) Cardiac-gated T2*-weighted fast low angle shot sequence acquired using 7T MRI shows Wilson pencils.

The "direct" and "indirect" pathways play crucial roles in movement disorder pathophysiology. Both traverse from the striatum to the internal pallidum and substantia nigra, the latter detouring to external pallidum and subthalamic nucleus. Anatomically, the pathways manifest within the striatofugal bundle that passes radially through the pallidum in the form of pencil-like tracts (first described by Wilson ${ }^{1}$; figure 1 ) before leaving the pallidum toward the substantia

\section{MORE ONLINE}

\section{$\rightarrow$ Teaching slides}

links.lww.com/WNL/

A850

From the Department of Neurology, Neuromodulation and Movement Disorders Unit (A.H., S.E.), Charité-University Medicine (CCM), Berlin, Germany; Department of Neurology (S.E., T.M.H.) and Athinoula A. Martinos Center for Biomedical Imaging, Department of Radiology (J.R.P.), Massachusetts General Hospital, and Department of Radiology (J.R.P.), Harvard Medical School, Boston; Department of Neurology (E.J.L.A., E.T.F.), University of São Paulo Medical School, Brazil; Institute of Neuroscience and Medicine (INM-1) (M.A.), Forschungszentrum Jülich GmbH; and Morphological Brain Research Unit, Department of Psychiatry (H.H.), University of Würzburg, Germany.

Go to Neurology.org/N for full disclosures. Funding information and disclosures deemed relevant by the authors, if any, are provided at the end of the article. 


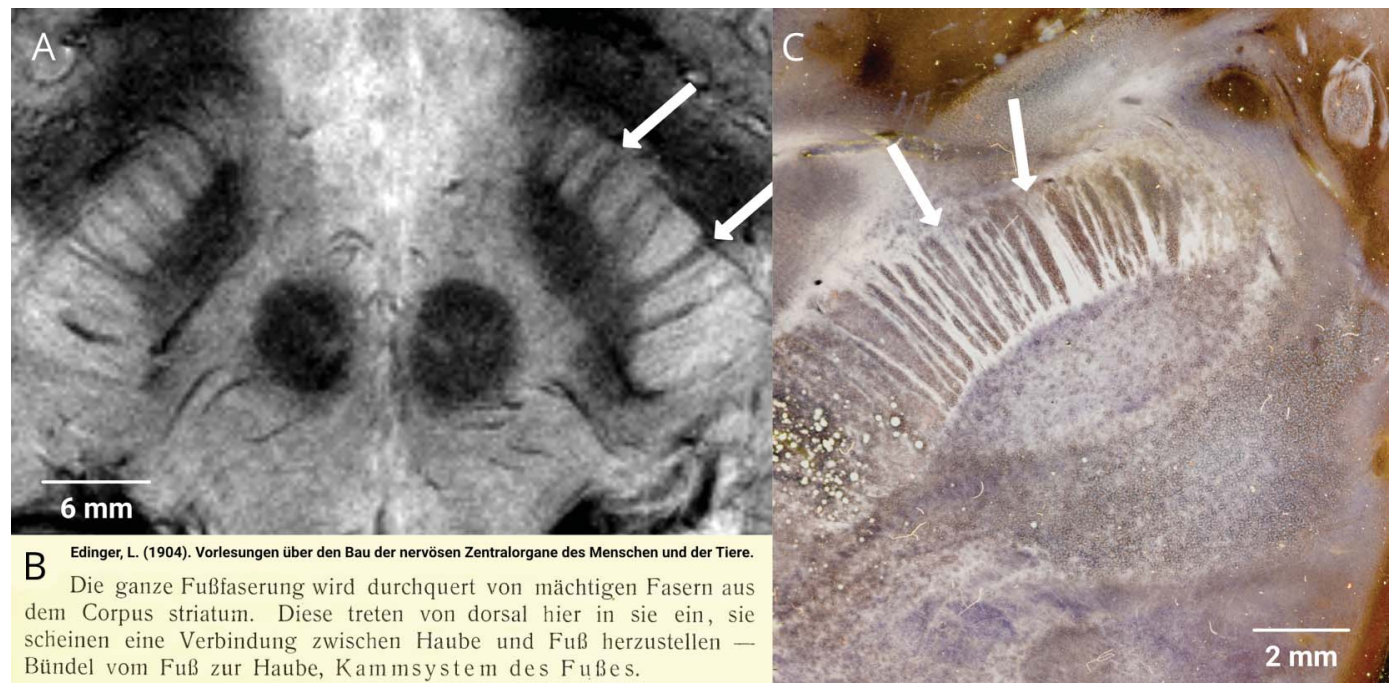

(A) Cardiac-gated fast low angle shot sequence shows Edinger comb. (B) First description: "The pedunculus cerebri is traversed by striatal fibers that enter dorsally and connect peduncle and tegmentum-bundle between peduncle and tegmentum, comb system of the peduncle." (C) Axial histologic section in dark-field microscopy demonstrates the human comb system.

nigra in the form of a comb described by Edinger in $1896^{2}$ (figure 2). A century later, these structures can be visualized in the living human brain (figures $1 \mathrm{D}$ and $2 \mathrm{~A}$ ).

\section{Author contributions}

A. Horn: drafting/revising the manuscript, data acquisition, study concept or design, analysis or interpretation of data, accepts responsibility for conduct of research and final approval, acquisition of data, study supervision. Siobhan G. Ewert: drafting/revising the manuscript, data acquisition, accepts responsibility for conduct of research and final approval, acquisition of data. Eduardo Joaquim Lopes Alho: drafting/revising the manuscript, accepts responsibility for conduct of research and final approval, acquisition and analysis of the dark field microscopy footage. M. Axer: data acquisition, accepts responsibility for conduct of research and final approval, acquisition of data, interpretation of measurements. H. Heinsen: drafting/revising the manuscript, data acquisition, analysis or interpretation of data, accepts responsibility for conduct of research and final approval, acquisition of data. Erich Talamoni Fonoff: drafting/revising the manuscript, data acquisition, accepts responsibility for conduct of research and final approval, acquisition of data. J.R. Polimeni: drafting/revising the manuscript, data acquisition, accepts responsibility for conduct of research and final approval, acquisition of data, study supervision, obtaining funding. T.M. Herrington: data acquisition, drafting/revising the manuscript, study concept or design, accepts responsibility for conduct of research and final approval, study supervision.

\section{Study funding}

No targeted funding reported.

\section{Disclosure}

A. Horn, S. Ewert, E. Alho, M. Axer, H. Heinsen, and E. Fonoff report no disclosures relevant to the manuscript. J. Polimeni reports funding by NIH NIMH R01-MH111438 and NIBIB P41-EB015896 and by the Athinoula A. Martinos Center for Biomedical Imaging. T. Herrington reports funding by NINDS grant K23NS099380 and an American Academy of Neurology/American Brain Foundation Clinical Research Training Fellowship. Go to Neurology.org/N for full disclosures.

\section{References}

1. Wilson SAK. An experimental research into the anatomy and physiology of the corpus striatum. Brain 1914;36:427-492.

2. Edinger L. Vorlesungen über den Bau der nervösen Centralorgane des Menschen und der Thiere. Für Ärzte und Studirende. Leipzig: F.C.W. Vogel; 1896. 


\section{Neurology}

\section{Teaching NeuroImages: In vivo visualization of Edinger comb and Wilson pencils}

Andreas Horn, Siobhán Ewert, Eduardo J.L. Alho, et al.

Neurology 2019;92; $1663-\mathrm{e} 1664$

DOI 10.1212/WNL.0000000000007252

This information is current as of April 1, 2019

\section{Updated Information \& Services}

References

Subspecialty Collections

Permissions \& Licensing

Reprints including high resolution figures, can be found at: http://n.neurology.org/content/92/14/e1663.full

This article cites 1 articles, 0 of which you can access for free at: http://n.neurology.org/content/92/14/e1663.full\#ref-list-1

This article, along with others on similar topics, appears in the following collection(s):

All Movement Disorders

http://n.neurology.org/cgi/collection/all_movement_disorders Dystonia

http://n.neurology.org/cgi/collection/dystonia

Motor Control

http://n.neurology.org/cgi/collection/motor_control

MRI

http://n.neurology.org/cgi/collection/mri

Parkinson's disease/Parkinsonism

http://n.neurology.org/cgi/collection/parkinsons_disease_parkinsonism

Information about reproducing this article in parts (figures,tables) or in its entirety can be found online at:

http://www.neurology.org/about/about_the_journal\#permissions

Information about ordering reprints can be found online:

http://n.neurology.org/subscribers/advertise

Neurology ${ }^{\circledR}$ is the official journal of the American Academy of Neurology. Published continuously since 1951, it is now a weekly with 48 issues per year. Copyright (O 2019 American Academy of Neurology. All rights reserved. Print ISSN: 0028-3878. Online ISSN: 1526-632X.

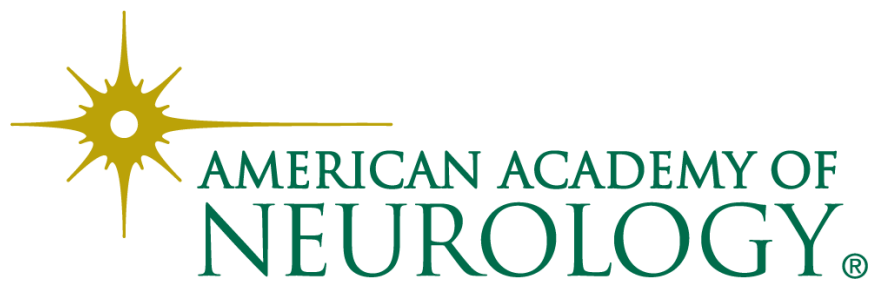

